The similarity of DNA sequences remaining bound to scaffold upon nuclease treatment of interphase nuclei and metaphase chromosomes

\title{
S.V.Razin*, V.L.Mantieva and G.P.Georgiev
}

Institute of Molecular Biology, USSR Academy of Sciences, Vavilov street 32, Moscow B-334, USSR

Received 8 June 1979

\begin{abstract}
The fragments of DNA attached to protein skeleton of interphase nuclei or metaphase chromosomes were obtained. Both the method invclving restriction endonuclease treatment $/ 1,2 /$ and a novel procedure based on mild staphylococcal nuclease digestion were used. In the latter case, DNA fragments remaining bound to nuclei or chromosomes are not enriched in satellite but only in abundant middle repetitive DNA. The shorter the fragments of attached DNA, the higher the content of middle repetitive DNA in the fraction. It has a slightly higher density in a CsCl gradient comparing to the main DNA. The jield of attached DNA, its distribution in a $\mathrm{CsCl}$ density gradient, and its renaturation properties are essentially the same for interphase and metaphase chromosomes. The average size of DNA loops was found to be equal to $60 \mathrm{~kb}$ for both metaphase chromosomes and interphase nuclei. The conclusion has been drawn that the bulk of attachment sites of DNP fibrils to axial chromosomal structures remains unchanged during the cell cycle.
\end{abstract}

\section{INTRODUCTION}

The previous studies from this and other laboratories |3-7/ have demonstrated the existence of a protein scaffold structure in interphase nuclei and metaphase chromosomes which were resistent to treatment with nonionic detergents and neutral salt solutions.

The DNA seemed to be tightly bound to them. If necessary precautions had been taken to avoid enzymatic degradation of DNA during isolation and dehistonization of nuclei and chromosomes with hish salt, almost all the INA could be obtained in the fast sedimenting complex with scaffold consisting of nonhistone proteins $16,8,9 /$. In the case of metaphase chromosomes the existence of large DNA loops fixed by both ends at the 
same sites on the scaffold has been demonstrated $/ 6,10,11,12 /$. The direct electron microscopic vizualisation of such loops in interphase nuclei is complicated but their existence was suggested on the basis of some biochemical experiments /13,14/.

In the previous papers, we have shown that upon the digestion of dehistonized metaphase chromosomes from mouse I cells with restriction endonucleases the DNA remaining bound to fast sedimenting protein structures was non-random but heavy enriched in abundant middle repetitive sequences $/ 1,2 /$. Also the high content of A-T-iich satellite was observed in attached DNA but it might be explained by a low susceptibility of the latter to the restriction endonucleases used.

In the present paper, we analyse the question whether the DNA remaining bound to the scaffold of interphase nuclei and metaphase chromosomes after nuclease digestion is the same. In addition to the method based on limit restriction endonuclease digestion, we elaborated and exploited a new technique for isolation of closely associated with the scaffold DNA based on mild digestion with staphylococcal nuclease. This procedure allowed to avoid the accumulation of the satellite in attached DNA fraction.

The main finding is that the bulk of the DNA remaining bound to scaffold structures upon different types of nuclease treatment are the same in metaphase chromosomes and in interfhase nuclei. This suggests the conservation of the DNA attachment sites during the cell cycle. The average size of DNA loops (the average length of DNA between the attachment points) calculated frow the obtained data also remains unchanged during the cell cycle.

\section{WATHRIALS AND METHODS}

The cells. Mouse I cells, clone 929 were grown in the complete kagle medium with $10 \%$ calf serum. As soon as cells covered $20 \%$ of the surface of the plate, they were put in methionine-free Eagle medium containing 10\% calf serum and then grow in the presence of $0.1 \mu \mathrm{Ci} / \mathrm{ml}$ [3 $\mathrm{H}$ thymidine $(12 \mathrm{Ci} /$ mmole; "Isotope", USSR) and $0.1 \mu \mathrm{Ci} / \mathrm{ml}$ [35 $\mathrm{S}$ methionine (1150 
Ci/mmole, "Amersham"). The cells were collected after 15-20 hrs of labeling. Alternatively, mitotic cells were accumulated by colcemide treatment and isolated 15-20 hrs later by shaking as was described previously $/ 1 /$. Interphase nuclei or metaphase plates were isolated using detergent treatment as was described previously $/ 1 /$.

Restriction endonuclease method for 1solation of attached DNA. Interphase nuclei were treated in about the same wor as was described earlier for metaphase plates $/ 1 /$. i nuclear suspension was made in sample buffer: $2 \mathrm{M} \mathrm{NaCl}, 10 \mathrm{mM}$ tris-HCl (pH 9), 10 mK EDIA, 0.1\% NP40, 0.1 mM PUSF (phenylmethylsulfonyl fluoride) at DKA concentration of $50 \mu \mathrm{g} / \mathrm{ml}$. After incubation for $1 \mathrm{hr}$ at $0^{\circ} \mathrm{C}$, the sample was centrifuged in a discontinuous gradient of $5 \mathrm{ml}$ of $60 \%$ sucrose in the buffer for EcoRI: $40 \mathrm{mM}$ tris-HCl, pH 7.6, $50 \mathrm{mM} \mathrm{NaCl}, 10 \mathrm{mM} \mathrm{MgCl}_{2}, 10 \mathrm{mM}$ 2-mercaptoethanol, $0.01 \% \mathrm{NP} 40$ (bottom) and $20 \mathrm{ml}$ of $15 \%$ gl scerol in the sample buffer. $10 \mathrm{ml}$ of nuclear suspension were lajered on each discontinuous gradient. Centrifugation at 15,000 rpm was performed in a SW27 rotor (Spinco, Beckman) for $45 \mathrm{~min}$ at $2^{\circ} \mathrm{C}$. The material concentrated at the border of the sucrose layer was diluted 20 times with the EcoRI buffer lajered on $60 \%$ sucrose in the same buffer and concentrated by centrifugation under the same conditions. It was collected thereupon and treated with endonuclease EcoRI. The digestion conditions were as follows: 2500 units of EcoRI endonuclease per ml of suspension of salt extracted nuclei at DNA concentration of about $250 \mu \mathrm{g} / \mathrm{ml} ; 1 \mathrm{hr}$ incubation at $37^{\circ} \mathrm{C}$. Thereafter the DNA remained bound to nuclei was collected by centrifugation in the same gradient as at the first dehistonization step.

Treatment of nuclei and metaphase plates with staphylococcal nuclease. Interphase or metaphase cells were suspended in buffer A containing $100 \mathrm{mM} \mathrm{NaCl}, 50 \mathrm{mM} \mathrm{KCl}, 20 \mathrm{mM}$ tris- $\mathrm{HCl}$ ( $\mathrm{pH} 7.5), 0.1 \mathrm{mM}$ EDTA, $0.1 \mathrm{mM}$ PMSF, and 10\% glycerol. NP40 was added to $0.5 \%$ and Triton $\mathrm{X}-100$ to $0.1 \%$. After $15 \mathrm{~min}$ incubation in an ice bath, the nuclei or metaphase plates were collected by centrifugation at $2000 \mathrm{~g}$ for $10 \mathrm{~min}$. The pellet was washed twice with buffer $A$ and then suspended in buffer $A$ at 
a DNA concentration of about $1 \mathrm{mg} / \mathrm{ml}$. It was heated to $25^{\circ} \mathrm{C}$, and $1 / 10$ of the volume of staphylococcal nuclease (Sigma) solution ( 1 unit/ml) in buffer $\mathrm{A}$ containing $20 \mathrm{mM} \mathrm{CaCl}_{2}$ was added. After incubation at different time intervals, the reaction was stopped by dilution with buffer B containing $10 \mathrm{mM} \mathrm{NaCl}, 20$ $\mathrm{mM}$ tris-HCl ( $\mathrm{pH}$ 9), $20 \mathrm{mM}$ EDTA, 0.2\% NP40, and 10\% glycerol.

Isolation of attached DNA from the nuclease-treated material. The sample in buffer $B$ was mixed with an equal volume of $3.9 \mathrm{M} \mathrm{NaCl}$ and, after extensive mixing, incubated for 45 min in an ice bath. Then it was layered on top of a gradient containing $5 \mathrm{ml}$ of $60 \%$ sucrose in a buffer containing $10 \mathrm{mM}$ tris-HCl ( $\mathrm{pH} \mathrm{9),} 10 \mathrm{mM} \mathrm{EDTA}, 2 \mathrm{M} \mathrm{NaCl}, 0.1 \% \mathrm{NP} 40$, and $20 \mathrm{ml}$ of $15 \%$ glycerol in the same buffer. Centrifugation was performed in a SW27 rotor (Spinco, Beckman) for $45 \mathrm{~min}$ at 15,000 rpm and $2^{\circ} \mathrm{C}$. The DNA attached to the residual structures of nuclei or chromosomes was concentrated at the border of the sucrose layer.

INA was isolated by the phenol-detergent method as described previously $/ 15 /$.

Determination of DNA molecular weight and calculation of the average size of loops. Double-stranded DNA was sedimented through a 5-20\% sucrose gradient in $1 \mathrm{kl} \mathrm{NaCl}, 1 \mathrm{mM} \mathrm{EDTA}, 10 \mathrm{mM}$ tris-HCl ( $\mathrm{pH} 7.0$ ) in $\mathrm{SW50.1}$ rotor (Beckman) at 40,000 rpm and $18^{\circ} \mathrm{C}$ for $3 \mathrm{hrs}$. DNA of the plasmid PBR-322 and INA of SV40 were used as markers. The molecular weight was determined on the basis of the following equation: $S_{20}, w=0.0882 \cdot M^{0.346} / 16 /$. Then the aveiage molecular weight of attached DNA was calculated as $M_{a v}=\sum C i / \Sigma \frac{C i}{M i}$ where $\Sigma C i$ is the total amount of DNA (in cpm) applied on the gradient and $\sum \frac{C_{i}}{\mathrm{Mi}}$ is the total number of chains in the preparation obtained by dividing the amount of DNA in each fraction ( $\mathrm{Ci}$ ) by the molecular weight of DNA in this fraction. For the calculation of the average size of loops the value obtained was divided by the figure characterizing the fraction of DNA remaining associated with the scaffold.

In the reassociation experiment, the molecular weight of denatured INA was determined by ultracentrifugation in a $5-20 \%$ sucrose gradient in $0.3 \mathrm{M} \mathrm{NaOH}, 0.5 \mathrm{kif} \mathrm{NaCl}, 1 \mathrm{mM}$ EDTA. 
The corditions were the following: rotor SW41 (Beckman); $30,000 \mathrm{rpm}$ for $16 \mathrm{hrs}$ at $18^{\circ} \mathrm{C}$. DNA prepared from core mononucleosomes was used as a marker. Its size was equal to 145 base pairs.

Ultracentrifugation in $\mathrm{CBCl}$ density gradient. The solution of $\mathrm{CsCl}\left(\rho=1.7 \mathrm{~g} / \mathrm{cm}^{3}\right)$ in $5 \mathrm{mM}$ tris-HCl ( $\left.\mathrm{pH} 7.0\right), 1 \mathrm{mM}$ EDTA and $0.2 \%$ sarkosyl was used. Centrifugation was performed in Ti 65 rotor (Beckman) at 40,000 rpm for $48 \mathrm{hrs}$.

DNA labeling with 32 (nick translation) was performed as described previously /17/: DNA polymerase I from M.luteus (Miles) and $\mathcal{L}\left[{ }^{2} \mathrm{P}\right]$ deoxyribonucleoside triphosphates with a specific activity of $450 \mathrm{Ci} /$ mmole (Amersham) were used.

Renaturation experiments. Before renaturation, DNA was cleaved into 200-300 nucleotide fragments by heating in $0.3 \mathrm{M}$ $\mathrm{NaOH}$. If necessary, it was fractionated in the alkaline sucrose gradient to collect this size fraction. The fraction renaturing at $C_{0} t 10^{-5}$ was removed by hydroxyapatite chromatography. The existence of such fast renaturing material depends on the formation of hairpin-like structures during nick translation, and does not reflect the genuine properties of investigated DNA. All renaturation experiments were performed under the conditions of high excess of total mouse DNA used as a driver. The hybrids were recovered by hydroxyapatite chromatography as described previously $/ 18 /$. The maximal renaturation at $c_{0} t=10^{4}$ moles $\times 1^{-1} \times$ sec was assumed as $100 \%$. Actually it varied from 80 to $90 \%$ for all preparation analysed.

\section{RESULTS}

1. Isolation and comparison of DNA fragments from nuclei and metaphase chromosomes remaining bound to the scaffold after treatment with restriction endonuclease

In the first series of experiments, we applied the technique of restriction endonuclease treatment to interphase nuclei. The method has been elaborated previously for metaphase chromosomes $11,2 /$. Isolated nuclel of mouse $l$ cells were dehistonized by centrifugation through $2 \mathrm{M} \mathrm{NaCl}$ and then digested with endonuclease EcoRI. 
It has been found that the procedure works equally well when it is applied to either interphase nuclei or metaphase chromosomes. The treatment of the nuclel by $2 \mathrm{M} \mathrm{NaCl}$ is known to remove all histones and most nonbistone proteins from DNA. On the other hand, high salt treatment does not destroy the nuclei themselves, as revealed by electron microscopy $13 /$. Even if DNA is digested by the nuclease, the nuclei survive and contain the nucleoli as well as thin filaments, nucleonems forming the so-called nuclear matrix /5/. If DNA is not damaged it remains bound to these residual nuclei in spite of the fact that it is readily soluble in $2 \mathrm{M} \mathrm{NaCl} / 8 /$.

In the centrifugation conditions used in our present work, the residual nuclei (as well as the residual metaphase chromosomes) passed through the $15 \%$ glycerol layer and were concentrated on the $60 \%$ sucrose cushion as can be seen on stained preparations in fluorescence microscope. The extracted proteins did not enter the glycerol layer.

Fig. 1 demonstrates the distribution of labeled DNA and
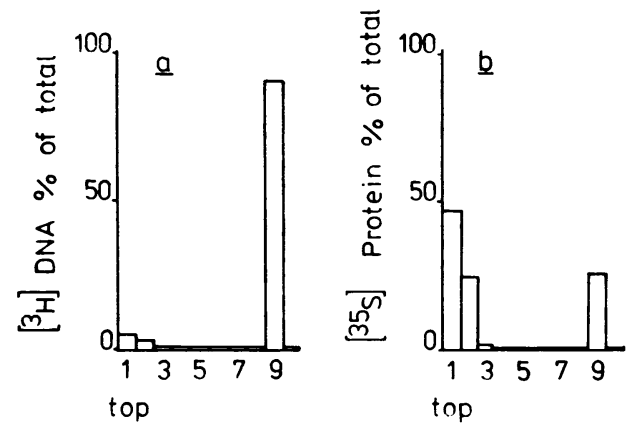

fraction number

Fif. 1. Distribution of DNA and protein upon centrifugation of interphase nuclei through $2 \mathrm{M} \mathrm{NaCl}$ in $15 \%$ gljoerol.

Undigested nuclei extracted with $2 \mathrm{~N} \mathrm{NaCl}$ were centrifugated (rotor SW27, "Beckman", $15000 \mathrm{rpm}, 45 \mathrm{~min}$ ). through $20 \mathrm{ml}$ of $15 \% \mathrm{glycerol}$ in $2 \mathrm{M} \mathrm{NaCl}, 10 \mathrm{mM} \mathrm{EDTA}, 10 \mathrm{mM}$ tris-HCl ( $\mathrm{pH} 9.0$ ), $0.1 \mathrm{mM}$ PMSF, $0.1 \%$ NP4O, underlayered with $5 \mathrm{ml}$ of $60 \%$ sucrose. The material was collected in 10 fractions after centrifugation.

(a) distribution of $3 \mathrm{H}$ DNA

(b) distribution of $35 \mathrm{~s}$ protein. 
proteins among the gradient fractions upon the treatment of non-digested nuclei with $2 \mathrm{M} \mathrm{NaCl}$. Almost all of the DNA ( $90 \%$ or more) remains bound to the fast sedimenting material and can be recovered on top of the concentrated sucrose layer where swelled nuclei are concentrated. About $10 \%$ of DNA was found on the top of the gradient, possibly because of partial degradation of the material during the extraction procedure. On the other hand, about $75 \%$ of ${ }^{35}$ S-labeled nuclear proteins were recovered in the top fraction and only about a quarter was still associated with the nuclear matrix. The latter figure is slightly higher than that for salt-treated metaphase chromosomes. One might expect this as the protein composition of the whole nucleus should be more complex than that of metaphase chromosomes.

The disruption of the protein skeleton of residual nuclei by digestion with pronase or by treatment with 4 M guanidine chloride leads to a complete loss of DNA from the glycerolsucrose interphase (Fig. 2a,b). The molecular weight of INA is not changed upon this treatment (data not shown), but even high molecular weight DNA cannot enter the glycerol lajer in centrifugation corditions used. Thus, the fast sedimentation of INA depends on its binding to the proteins of dehistonized residual nuclei.

On the other hand, even the exhaustive removal of DNA from residual nuclei by DNase I treatment does not decrease the amount of protein in the fast sedimenting material (Fig. 2d). In fluorescence microscope the residual nuclei can be seen in the glycerol-sucrose interphase.

To obtain the DNA Iraction enriched in sequences adjacent to the points of attachment of DNA molecules to the elements of protein nuclear matrix, the dehistonized nuclei were treated by EcoRI endonuclease and then the centrifugation through 2 M $\mathrm{NaCl}$ in 15\% glycerol was repeated.

After exhaustive EcoRI treatment of salt-extracted nuclei, only $3-5 \%$ of the total ${ }^{3} \mathrm{H}$-labeled DNA still remains attached to the nuclear material (Fig. 3). This figure is higher than that reported previously for metaphase chromosomes /1/. However, this depends on certain modifications of the isolation 


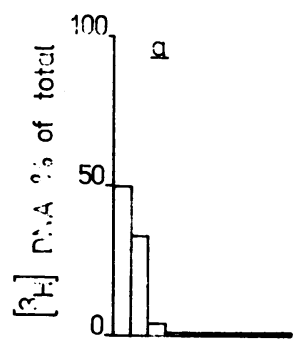

top

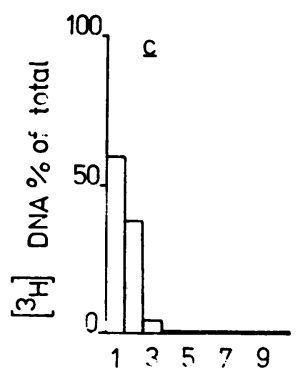

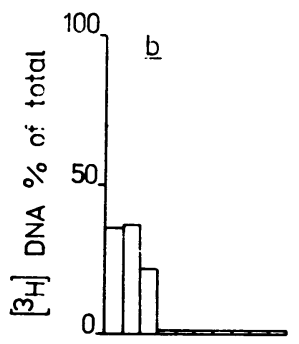

top

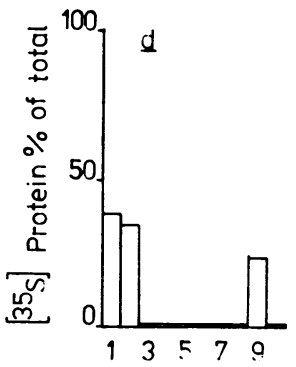

fraction number

Fig. 2. Distribution of DNA and protein upon centrifugution of interphase nuclei digested with different enzymes or treated with 4 guanidine chloride through 2 ii $\mathrm{NaCl}$ in $15 \%$ glycerol. in Fig. 1.

The conditions of centrifugation were the same as

(a) The nuclei treated with 4 ki guanidine chloride (DNA).

(b) The nuclei treated with Pronase (INA).

(c) The nuclei treated with DNase I (DNA).

(d) The nuclei treated with DNase I (protein).

procedure (see liethods) which eliminated the loss of attached DNA durins centrifugation. If the same improved procedure is applied to metaphase chromosomes, the yield of DNA remaining bound to the scaffold upon the limit digestion with EcoirI also accounts to $3-5 \%$ (Table 2).

The attached DNA from interphase nuclei was banded in a $\mathrm{CsCl}$ density gradient (Fig. 4). About two-thiras of the material was recovered in the light peak with the buoyant density 


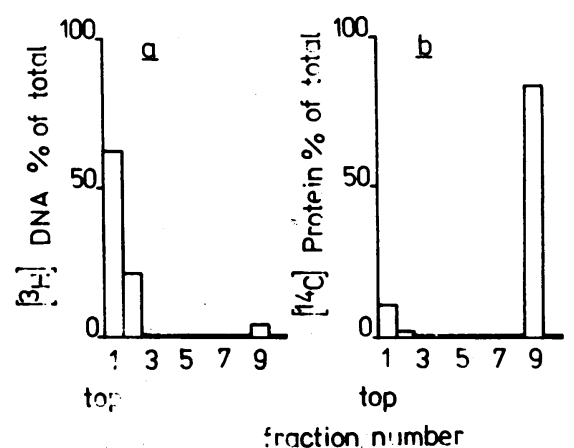

Fig. 3. Distribution of DNA (a) and protein (b) upon centrifugation through $2 \mathrm{M} \mathrm{NaCl}$ in $15 \%$ glycerol of dehistonized nuclei after limit digestion with EcoRI. Fig. 1.

The conditions of centrifugation were the same as in

typical of mouse satellite $\left(1.69 \mathrm{~g} / \mathrm{cm}^{3}\right)$ and about a third in the denser ratber broad band $\left(\rho=1.70-1.71 \mathrm{~g} / \mathrm{cm}^{3}\right)$. The distribution is similar to that described previously for attached DNA from metaphase chromosomes $/ 1,2 /$.

The material from the both regions (see Fig. 4) was collected separately, labeled with $32 \mathrm{P}$ by nick translation, and then analysed in renaturation experinents with an excess of total DNA used as a driver (Fig. 5).

The DNA of the light peak behaves as a typical satellite renaturing at $C_{0} t_{1 / 2}=5 \cdot 10^{-3}$ moles $\times 1^{-1} \times$ sec. In the DNA from the heavy band, a sigalficant proportion ( $30 \%)$ of the material renatures in the $c_{0} t$ interval between $10^{-2}-10^{\circ}$ moles $\times 1^{-1} \times$ sec. Thus, the renaturation kinetics of attached DNA fraction in interphase nuclei is also similar to that for metaphase chromosomes.

The accumulation of satellite DNA may be easily explained in terms of its known unsusceptibility to EcoRI endonuclease $119 /$. To test this possibility, the heavy and light DNA fractions were ultracentrifuged in a neutral sucrose gradient for size determination (Fig. 6). The average size of DNA 


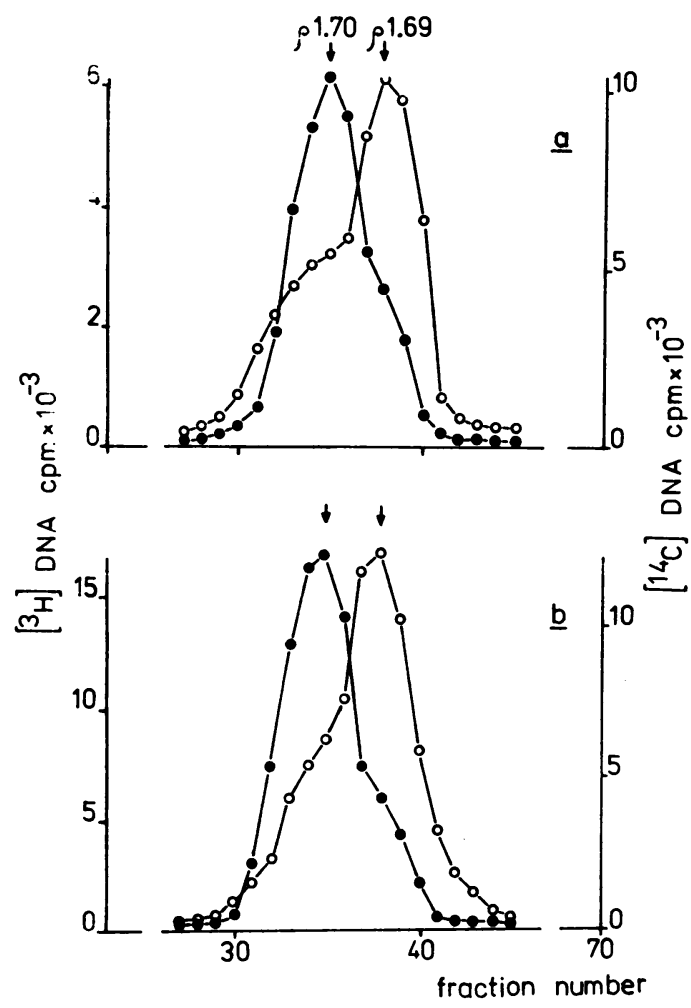

Fig. 4. CsCl density gradient ultracentrifugation of scaffold bound DNA obtained from interphase nuclei ana metaphase chromosomes with the aid of limit digestion by enconuclease EcoRI.

The solution contained scaffold bound $3_{\mathrm{H}} \mathrm{DNA}(0-0)$ and total mouse $14 \mathrm{C}$ DrrA (-0) used as an internal marker in $\mathrm{CsCl}$ at a density of $1.7 \mathrm{~g} / \mathrm{cm}^{3}$. Centrifugation was performed in a Ti65 rotor (Beckman) at $40000 \mathrm{rpm}$ for $48 \mathrm{hrs}$. 70 fractions were collected for analysis. Only the middle part of the gradient containing analysed DNA is presented in the figure.

(a) Scaffola bound DNA from interphase nuclei.

(b) scaffold bound DNA from metaphase chromosomes.

fragments in the light peak is $(6.5-10) \times 10^{3}$ base pairs while it is only $1.6 \times 10^{3}$ in the heavy one. Thus, due to a much higher content of EcoRI sites in the main band of DNA as compared to satellite, the former is cut much closer to the attachment 


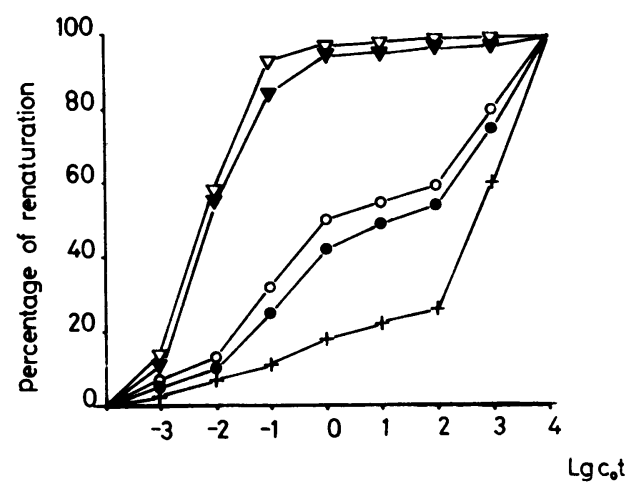

Fig. 5. Renaturation properties of the light and heavy components of scaffold bound DNA prepared from interphase nuclei by the endonuclease EcoRI technique.

The renaturation curves for the same fractions from metaphase chromosomes / / are given to facilitate comparison.

$\nabla-\nabla$ light component of scaffold bound DNA from metaphase chromosomes;

$\nabla-\nabla$ inght component of scaffold bound DNA from interphase nuclei;

O-O heavy component of scaffold bound DNA from metaphase chromosomes;

- heavy component of scaffold bound DNA from interphase nuclei;

$+-t$ total mouse DNA.

Tracer amounts of ${ }^{32} \mathrm{P}$ DNAs were annealed to a high excess of unlabeled total DNA used as a driver (seo Cot values). The size of DNA in renaturing experiments was equal to 200400 base pairs ( 300 on the average).

points to nuclear matrix. Therefore, the fragment size and the total amount of the DNA is denser fraction decrease.

2. Isolation of DNA fragments attached to the nuclear or chromosomal scaffold with the aid of staphylococcal nuclease

As was mentioned above, the use of restriction endonucleases introduced non-randomness in the DNA digestion. Another problem was the durability and complexity of the procedure during which some material may be lost due to aggregation and or degradation. To avoid these uncertainties, we used in fur- 


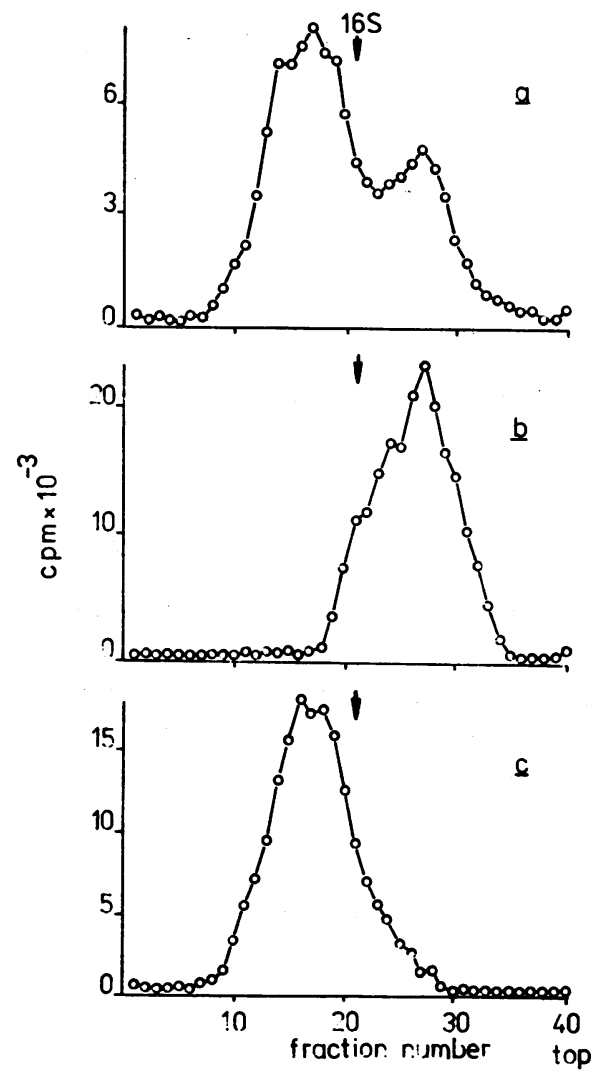

Fig. 6. Ultracentrifugation of the preparations of scaffold bound DNA in a neutral sucrose gradient.

DNA was layered on a 5-20\% sucrose gradient and centrifuger. in a SW 50.1 rotor at $40,000 \mathrm{rpm}$ for $3 \mathrm{hrs}$. SV40 and $\mathrm{pBr}-322$ DNAs were used as markers.

(a) Scaffold bound DNA obtained with the aid of scoRI treatment (without fractionation in a CsCl density gradient).

Note the bimodal di tribution of the material.

$(b, c)$ Dense enä li ht subfractions (respectively) of the scaffold bound DNA obtained with the aid of EcoRI treatment. both cases.

Note the unimodal distribution of the material in

ther experiments, treatment of metaphase chromosomes or interphase nuclei with staphylococcal endonuclease followed by $2 \mathrm{M}$ $\mathrm{NaCl}$ extraction. By varying the time of digestion, one can 
cleave any amount of DNA from the nuclear or chromosomal scaffold. A typical kinetic experiment is represented in Fig.7. After extensive digestion, practically no DRA can be detected. in the fast sedimenting material. Actually, the figure is as lor as $0.1 \%$ or even less. Considering the size of a loop to be equal to $60 \mathrm{~kb}$ (see below) one may sonclude that the size of a fragment protected against staphylococcal nuclease is very small being equal to or less than 50 base pairs. If DRA is attached to the axial structures just at a few points and each nuclease break is reallzed in the removal of the distal part of a loop from the scaffold, one should expect a good correlation between the average size of DNA fragments remaining bound to the fast sedimenting structures and the total amount of this attached DNA.

To check this, we isolated attached DNA at different stages of digestion, determined its distribution in a neutral sucrose gradient and calculate the average size of the DNA fragments (Table 1). In Fig. 8, an example of attached DNA distribution in sucrose gradient at one of points of digestion

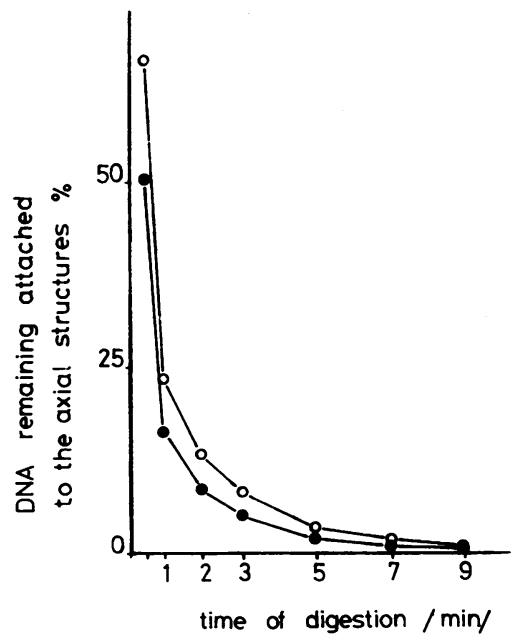

Fig. 7. Kinetics of the cleavage of DNA from scaffold during digestion with staphylococcal nuclease.

O-O lietaphase chromosomes.

- Interphase nuclei. 


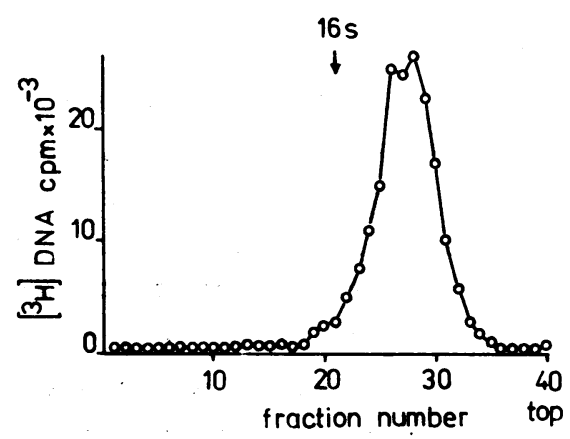

Fig. 8. Ultracentrifugation of scaffold bound DNA obtained with the aid of Staphylococcal nuclease treatment ( $2 \%$ of total LIA) in a neutral sucrose gradient.

Centrifugation conditions were the same as in Fig. 6.

with staphylococcal nuclease is presented. The distribution is unimodal. Similar unimodal distribution patterns were obtained in all other experiments (data not shown). One con see that the average size of bound DNA decreases in proportion to its amount (Table 1). The average size of a loop (the average distance between the attachment points of the DNA molecule) was calculated from these figures. Some variations were ob-

Table 1. Relationship between the amount of DNA remaining bound to scaffold and its average molecular weight

\begin{tabular}{|c|c|c|c|c|}
\hline \multirow[t]{2}{*}{$\begin{array}{l}\text { Material } \\
\text { used }\end{array}$} & \multirow{2}{*}{$\begin{array}{l}\text { Amount of } \\
\text { DNA remain- } \\
\text { ing bound } \\
\text { to a scaf- } \\
\text { fold, } \% \text { of } \\
\text { total }\end{array}$} & \multirow{2}{*}{$\begin{array}{l}\text { Average } \\
\text { size of } \\
\text { DrA } \\
\text { fragments, } \\
\text { kb }\end{array}$} & \multicolumn{2}{|c|}{$\begin{array}{l}\text { Average distance } \\
\text { between two attach- } \\
\text { ment gites } \\
\end{array}$} \\
\hline & & & $\mathbf{k b}$ & average $\mathbf{k b}$ \\
\hline $\begin{array}{l}\text { Metaphase } \\
\text { chromo- } \\
\text { somes }\end{array}$ & $\begin{array}{r}5 \\
16 \\
25\end{array}$ & $\begin{array}{l}3.5 \\
8.2 \\
16\end{array}$ & $\begin{array}{l}70 \\
51 \\
64\end{array}$ & 61.6 \\
\hline $\begin{array}{l}\text { Interphase } \\
\text { nuclei }\end{array}$ & $\begin{array}{r}2 \\
10 \\
18 \\
25\end{array}$ & $\begin{array}{l}1.2 \\
7 \\
12 \\
13\end{array}$ & $\begin{array}{l}60 \\
70 \\
67 \\
52\end{array}$ & 62.2 \\
\hline $\begin{array}{l}\text { The average } \\
\text { from all } \\
\text { experiments }\end{array}$ & - & - & $62 \pm 8$ & \\
\hline
\end{tabular}


served at different experimental points but they were always in the range of 50 to $70 \mathrm{~kb}$. The average figure is $\sim 60 \mathrm{~kb}$. It is again the same for either metaphase chromosomes or interphase nuclei (Table 1).

The possibility that differences in the chromatin structure in different parts of nuclel moy induce some non-randomness in DRA digestion has not been excluded in the above experiments. Therefore, we changed the order of procedures in some cases. The nuclei were first dehistonized and then digested with staphylococcal nuclease. Although digestion in this case procedes faster, the results are essentially the same. The sedimentation and renaturation properties (see below) of attached DNA fragments obtained after cleavage from the scaffold of a certain DNA fraction were the same regardless of the order of treatment (data not shown).

These results support the conclusion about random cleavage of DNA loops with staphylococcal nuclease. Therefore, in most of the experiments, we used the original order of treatments (first digestion and then dehistonization) as it is much easier and allows to work with higher amounts of the material.

3. Properties of attached DNA fragments obtained in experiments with staphrlococcal nuclease

The method involving staphylococcal nuclease treatment allows one to isolate DNA fragments cut at any distance from the point of attachment to the axial structure. First, the distribution of such fragments in a CsCl density gradient was analysed. Fractions with the average DNA size of about $0.15 \times 10^{3} ; 0.3 \times 10^{3} ; 0.9 \times 10^{3}$ base pairs were prepared from DNA samples bound to the matrix of interphase nuclei amounted as much as $0.25,0.5$ and $1.5 \%$ of the total DNA, respective1y. In a CsCl density gradient (Fig. 9) neither of these fractions was found to be enriched in AT-rich satellite in contrast to DNA obtained with the aid of EcoRI endonuclease.

On the other hand, the position of the peak for attached DNA shifts to a higher density $\left(-1.71 \mathrm{~g} / \mathrm{cm}^{3}\right)$ comparing to total mouse DNA. The shorter the DNA analysed, the more prominent the shift of its buoyant density. Thus, the buojant den- 


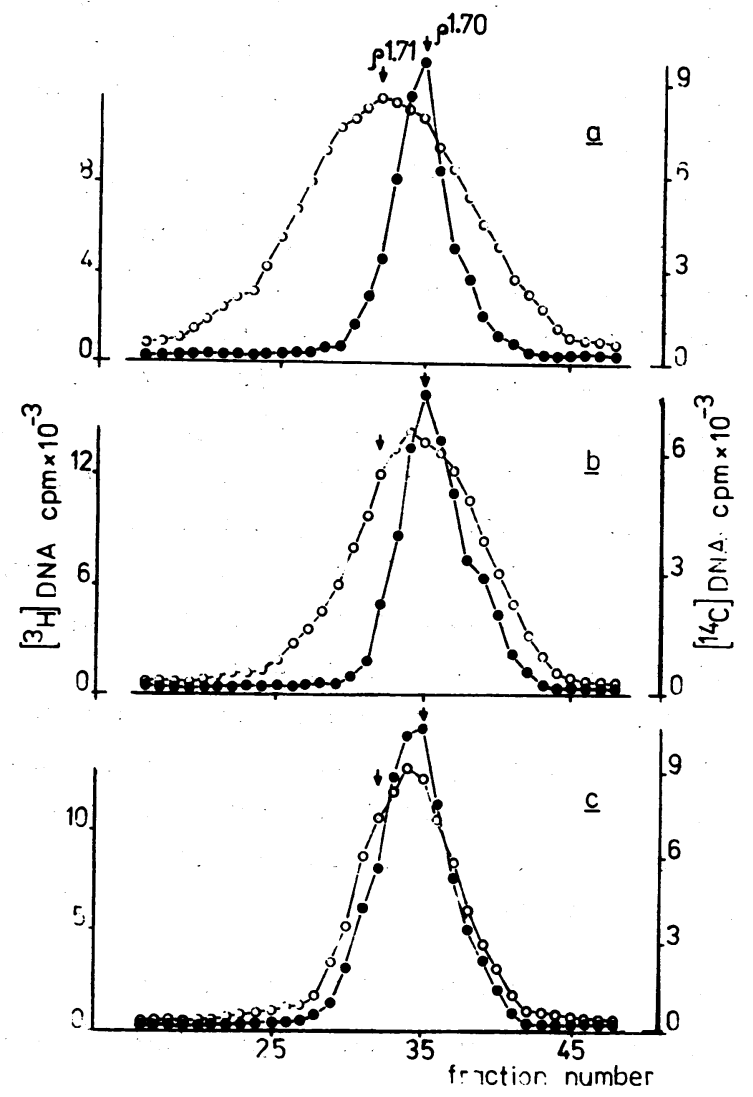

Fig. 9. CsCl density gradient ultracentrifugation of scaffold bound DNA obtained from interphase nuclei using the staphylococcal nuclease procedure.

The conditions of ultracentrifugation are as in Fig. 2.

o-O Scaffold bound $3 \mathrm{H}$ DNA from interphase nuclei.

- Total 14C DNA with high molecular weight. Scaffold bound DNA with the average size of $0.15(\mathrm{a}) ; 0.3$ (b) and 0.9 (c) $\mathrm{kb}$ were analysed.

sity and consequently the $G+C$ content for DNA adjacent to the attachment site is somewhat higher than those for the total main DNA. In spite of the fact that the peaks were rather broad, the difference is quite significant. In control experiments where the total DNA sheared to the same size as at- 
tached DNA was centrifuged it was also banded as a very broad peak (due to increased diffusion) but the latter was not shifted comparing to the non-sheared marker (Fig. 10). ExactIf the same distribution in a $\mathrm{CsCl}$ density gradient was ojtained with the material from metaphase chromosomes (data not shown).

Then renaturation experiments were performed with bound

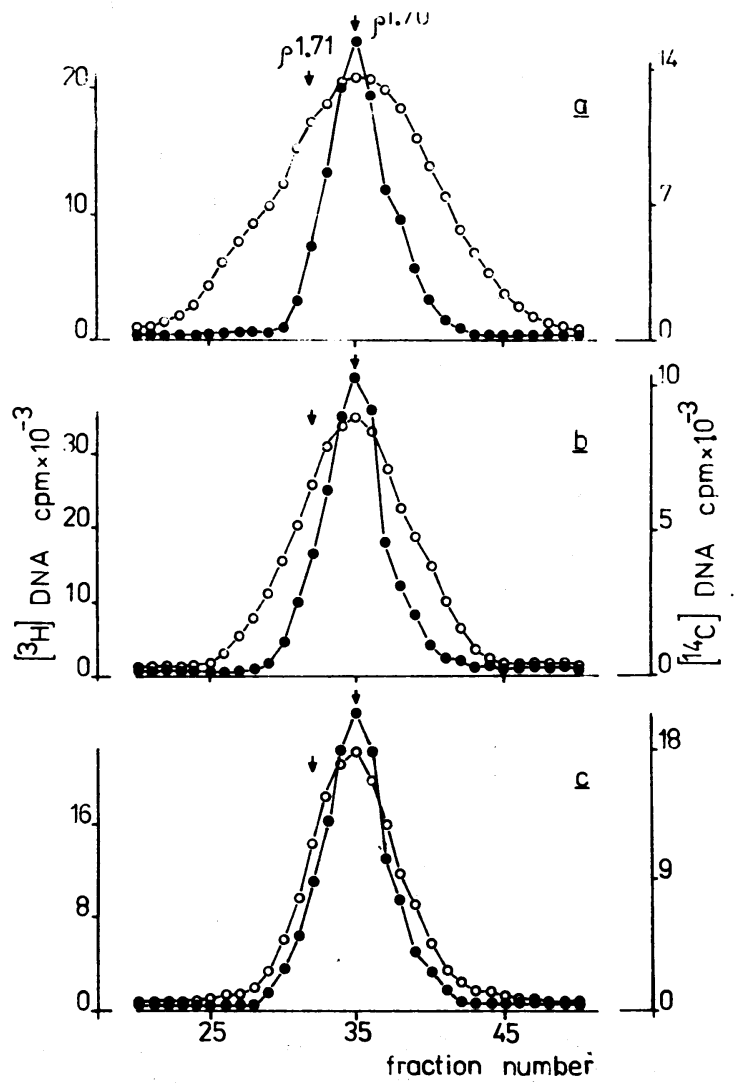

Fig. 10. CsCl density gradient ultracentrifugation of total mouse DNA sheared to 0.15 (a), 0.3 (b) and 0.9 (c) $\mathrm{kb}$.

The conditions of centrifugation as in Fig. 2.

0-0 ${ }^{3} \mathrm{H}$ sheared DNA.

- Narker 14C with high molecular weight. 
DNA fragments of $1 \times 10^{3}$ and $5 \times 10^{3}$ base pairs. They were labeled by nick translation, sheared, and renatured in the presence of a large excess of total mouse DNA used as a driver (Fig.11).

One can see tilat the fraction of attached DNA with an average eragment size of $1 \times 10^{3}$ base pairs differs significantIf from the total DNA according to renaturation kinetics. It
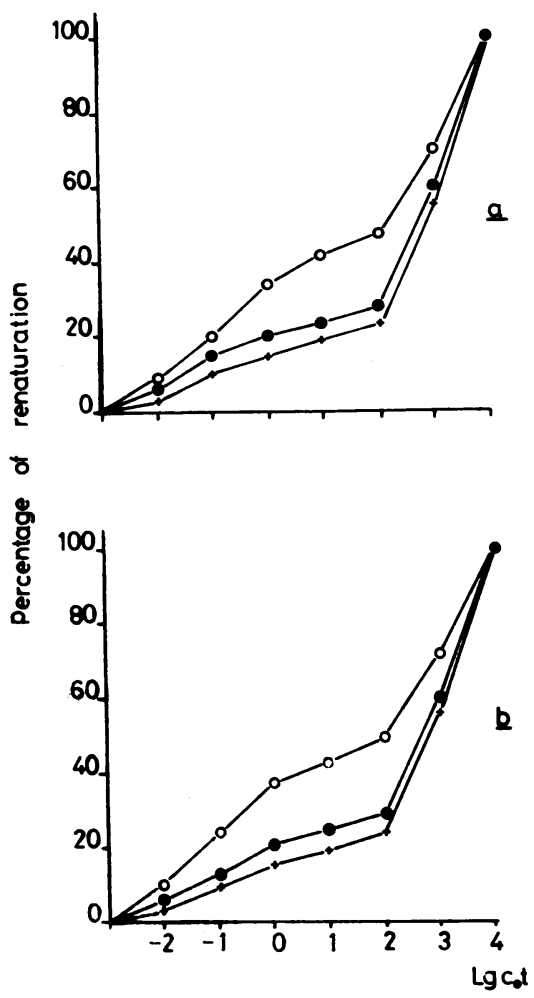

Fig. 11. Renaturation curves of scaffold bound DNA of different lensth obtained using staphylococcal nuclease technique.

(a) Bound DNA of metaphase chromosomes.

(b) Bouna DNA of interphase nuclei.

0-O Bound DNA with an average size of $1 \mathrm{~kb}$.

- - B Bound DNA with an average size of $5 \mathrm{~kb}$.

t-t Total mouse DHA.

ill DFis samples were sheared to 200 nucleotide fragments befure renaturation. 
contains a much higher proportion of sequences renaturing in the $\mathrm{c}_{0} \mathrm{t}$ interval from $10^{-2}$ to $10^{\circ}$ moles $\times 1^{-1} \times$ sec. The content of this fraction is about $25 \%$.

This Pigure is somewhat lower than that obtained in the experiment presented in Fig. 5 with attached DNA prepared with the aid of EcoRI endonuclease. However, the difference is easiif explained by the variation in the size of fragments used in the renaturation. The DNA was sheared before renaturation to 200 base pair Iragments in the experiment described in Fig.11 and to 300 base pairs on the average in the case presented in Fig. 5. Taking this into account, one may conclude that the attached DNAs obtained from the two experiments are very similar in respect to the content of abundant middle repetitive sequences.

On the other hand, the content of fast renaturing satellite DNA is not high in the attached DNA prepared with the aid of staphylococcal nuclease. It is of the same order or even less than in total mouse DNA.

Apart from abundant middle repetitive INA, less repetitive and single-copy DNAs are also present in $1 \times 10^{3}$ base pairs fragments. If attached DNA of $5 \times 10^{3}$ base pairs is studied, their content increases and the renaturation curve becomes similar to that of total DNA. Thus, repetitive DNA is located closely to the point of attachment to the scaffold and on the other side linked to less repetitive and single-copy DNA.

It should be pointed out again that the renaturation curves obtained with DNA fragments isolated from metaphase chromosomes and interphase nuclei are quite similar.

\section{DISCUSSION}

The scaffold model of metaphase chromosome organization although not proved unequivocally is gaining increased acceptance. The most clear evidence was obtained in the experiments by Laemmli et al. $16 /$. In the case of interphase nuclei possibIy due to the unfolding of filaments, the scaffold consists of, the electron microscopic pictures cannot be easily interpreted.

However the previously published $/ 8,13,14 /$ and presented 
in this paper data suggest the existence of similar structures also in the interphase nuclei. The behaviour of DNA and proteins upon different treatments of metaphase chrowosomes and interphase nuclei was essentially the same. The demonstration of non-randomness of DNA remaining bound to the scaffold upon nuclease treatment $/ 1,2 /$ as well as its sinilarity in tive case of metaphase chromosome and interphase nuclei (this paper) gave further support to the general model.

The present paper describes a simple one-step method for the isolation of DNA closely associated with the protein axial structures of metaphase chromosomes or interphase nuclei. This method involving staphylococcal nuclease treatment followed by centrifugation in a glycerol gradient containing $2 \mathrm{M} \mathrm{NaCl}$ has several advantages to the previously described technique based on restriction nuclease digestion. The former is much simpler. It allows to obtain fragnents of attached INA of any desirable length. Finally, it provides random cleavage of DNA loops independently of sequences present in them. This eliminates the enrichment of bound DNA preparations with satellite sequences.

The oaly INA fraction which is present in attached DNA in a much higher amount than in total DNA is the fraction renaturing in a $c_{0} t$ range of $10^{-2}$ to $10^{\circ}\left(c_{0} t_{1 / 2}=10^{-1}\right.$ mole: $\times 1^{-1} \times$ sec). This DNA containing sequences represented more than $10^{4}$ times in the haploid mouse geriome is accumulated in short fragnients of the attached DNA. Thus, such repetitive DNA sequences are located closely to the attachment sites anc may be involved in the interaction with scaffold proteins.

It is interesting that the average base composition of DNA sequences adjacent to the attachment sites difiers from that of bulk DNA and is characterized by a higher G+C content.

Clones containing DNA which efficiently hybriàizes to attached DHA have been obtained recently in our laboratory. Some of theil contain DNA fragments binding a significant proportion $(15-20 \%)$ of $1 \mathrm{~kb}$ attached DNA which was sheared to 200 base pairs fragments before hybridization (manuscript in preparation). This result directly proves the existence of similar Divi sequences at the basement oi many different loops. 
Randomness of DNA cleavage by staphylococcal nuclease made it possible to measure more accurately the length of DNA loops between the points of their attachment to protein axial elements.

The size of DNA loops determined from sevel different experiments with various degree of DNA cleavage is rather similar. All figures obtained are confirmed within the range of 50 to $70 \mathrm{~kb}$ ( $62 \mathrm{~kb}$ on the average). These figures are close to those obtained in a different way by other authors $16,13,14 /$. This size is comparable with that of a structural-functional unit of eukaryotic chromosomes, like bands of polytene chromosomes or chromomers.

The most interesting result obtained in the present work is a dewonstration of similarity in the DNA adjacent to attachment sites in metaphase chromosomes and interphase nuclei. In all experiments where various tests were used, we could detect no differences in the properties of attached DNA obtained from the two sources. The same type of repetitive DNA sequence was observed in the both. The latter result was confirmed in the above mentioned experiments with cloned DNA fragments. The results showing a close similarity between interphase nuclei and metaphase chromosomes are summarized in Table 2. Of course, in the experiments described, minor differences can be easily missed. For example, there is some evidence for temporary association of replicative forks with the matrix of interphase nuclei $/ 5 /$. However, the concentration of replicative forks at any given time is very low and cannot influence the properties of the total fraction of attached INA.

Probably, at least the bulk of DNA attachment sites is not changed when the cell passes from mitosis to interphase and back. The general plan of chromosome organization remains the same. Therefore, strikins differences in the distribution of chroinatin may depend mostly on changes in the arrangement of axial filaments of chromosomes. nucleonems, during the cell cycle /20/. At the interphase, these elements may either be spread on the inner layer of the nuclear membrane or pass inside the nucleus. Durins the mitosis, they can condense possibly by forming helical structures. As a result, an easily 
Table 2. Comparison of attached DNAs from metaphase chromosomes and interphase nucle1

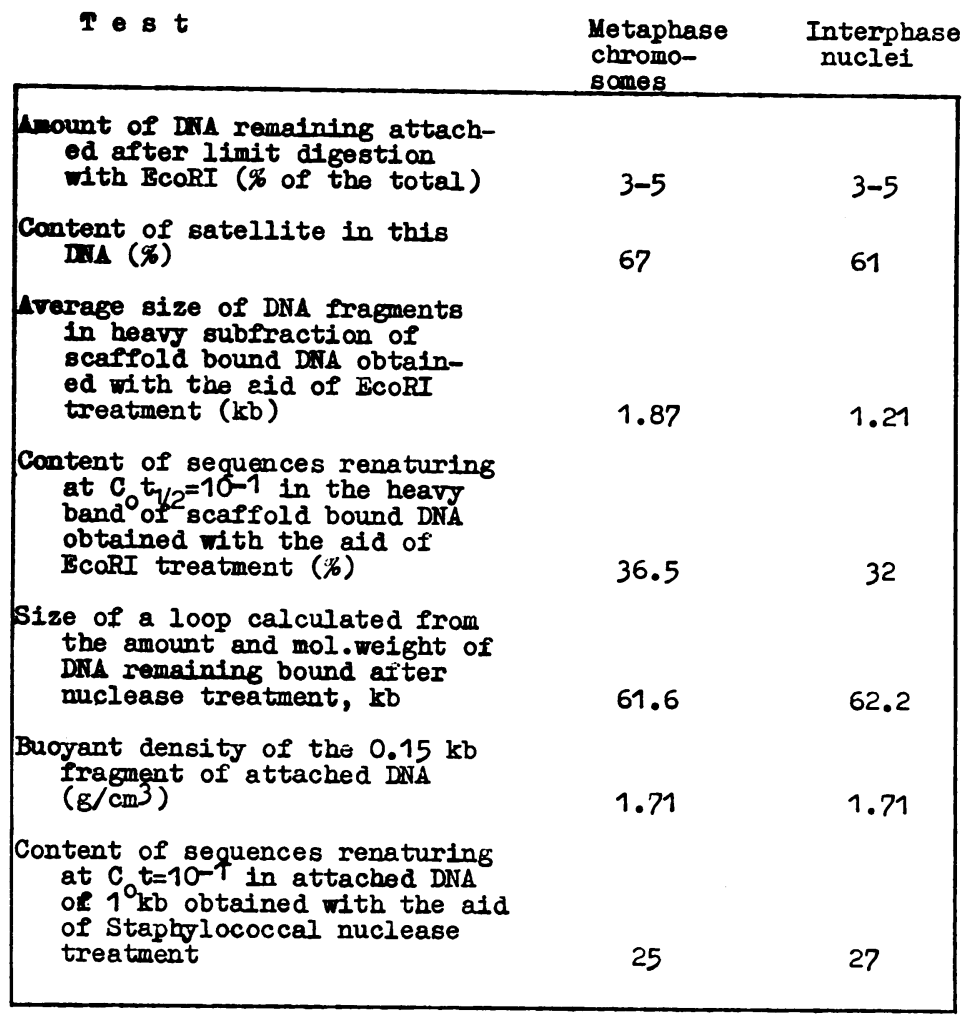

visualized metaphase chromosome scaffold is formed.

Further work is necessary to understand the interaction between the pruteins of axial elements and specific DNA sequences and mechanisms of chromosome transformatious auring: the cell cycle.

\section{BEHERFNCES}

1 Razin, S.V., Mantieva, V.I. and Georgiev, G.P. (1978) Nucleic Acids Res. 5, 4737-4751.

2 Wantieva, V.I., Razin, S.V. and Georgiev, G.P. (1979)

Hol. Biol. (USSR) in press.

3 Georgiev, G.P. and Chentsov, Yu.S. (1960) Proc.Acad.

Sci. JSSR 132, 199-202.

4 Smetana, K. Steele, W.J. and Busch, H. (1963) Exptl.Cell Res. 31, 198-201. 
5 Berezney, R. and Coffey, D.S. (1977) J.Cell Biol. 13. 616-637.

6 Iaemmli, U.K., Cheng, S.M., Adolph, K. W., Paulson, J.3. Brown, J.A. and Baumbach, W.R. (197?) Cold Spring Faris Symp. Quant. Biol. 42, 351-360.

7 Adolph, K.W., Cheng, S.H., , Paulson, J.R. and Iaent. U.K. (1977) Proc.Nati.Acad.Sci.UAA 11, 4937-4941.

8 Cook, P.R. and Brazel, I.A. (1976) J.Cell. Sci. 22,201-2

9 Vanka, F., Mullenders, I.H.F., Bekers, A.G.M.. Pennins I.J., Aelen, J.H.A. and Eygensteyn, J. (1977) Blochem Biophys. Res- Communs. 74, 739-747.

10 Wray, W., Hace, M., Jr., Daskal, Y. and Stubleriela, I. (1978) Cold Sprin.' Harbor Symp.' Quant. Biol. 42.39250

11 Ris, H. (1978) J.Cell Biol. 79, 2, pt.2, 10\%a.

12 Ratner, J.B. and Hamkalo, B.A. (1978) Chromosoma 69 369-372.

13 Benjajati, C. and Wcircel, A. (1976) Cell 2, 393-nol-

14 Igo-Kemenez, W.T. and Zachau, H.G. (1977) Cold Spring Harbor Symp. Quant. Biol. 42, 109-118.

15 Georgiev, G.P. In: "The Nucleic Ac1ds" (I.B.Zbars al S.S.Debov, eds.) Medicine, Ieningrad (1969) pp.jh

16 Studier, F. (1965) J.Mol.Biol. 11, 373-390.

17 Rigby, P.W.S., DHeckmann, $\mu_{0}$, Rhodes, C. and Bars, $\mathbf{P}_{-}$ (1977) J.Hol.Biol. 113, 237-252.

18 Britten, R.J., Gracham, D.E., Neufeld, B.5. (1974) zach "Methods in Enzymology" v.29, pp.363-418.

19 Botchan, M., Mckenna, G. and sharp, P.A. (1973) Spring Harbor symp. Quant. Biol. 42, 351-360.

20 Ceorgiev, G.P., Nedospasov, S.A. and Bekraver. J.J. (1978) In "The Cell Nucleus, Chromatin, part $C^{\circ}$ ed.) Academic Press, Net York, San Iransisco, Iennm vol. $6, \mathrm{P}_{\mathrm{s}} \cdot 4-34$. 